\title{
Cerebral metabolism, anatomy, and cognition in monozygotic twins discordant for dementia of the Alzheimer type
}

\author{
J S LUXENBERG, ${ }^{*}$ C MAY,* J V HAXBY,* C GRADY, ${ }^{*}$ A MOORE, ${ }^{*}$ G BERG,${ }^{*}$ \\ B J WHITE, $\dagger$ D ROBINETTE $\ddagger$ S I RAPOPORT*
}

From the Laboratory of Neurosciences, ${ }^{*}$ National Institute on Aging, and Section on Cytogenetics, $\dagger$ Laboratory of Cellular Biology and Genetics, National Institute of Arthritis, Diabetes, Digestive and Kidney Diseases National Institutes of Health, Bethesda, and the National Academy of Sciences, $\ddagger$ National Research Council, Washington, USA

SUMMARY One pair of monozygotic twins discordant for dementia of the Alzheimer type (DAT) was studied using neuropsychological testing, quantitative $x$-ray computed tomography (QCT) and magnetic resonance imaging (MRI) of the brain. Cerebral glucose metabolism was measured using positron emission tomography (PET) and 2-[18-F]fluoro-2-deoxy-D-glucose (FDG). The affected twin had a seven year history of progressive cognitive impairment and was severely demented. Neuropsychological testing of the affected twin demonstrated marked deficits in all areas of cognitive function. The asymptomatic twin showed some impairment on tests of perceptual organisation and delayed recall. The affected twin had loss of gray matter and ventricular enlargement on QCT and MRI compared with healthy controls $(p<0.05)$. He also had frontal and parietal lobe hypometabolism and increased asymmetry of metabolism on PET compared to both his twin and healthy age-matched controls $(\mathrm{p}<0.05)$. PET, QCT, and MRI distinguished changes in the twin with DAT compared with his brother and healthy controls. Although the subtle neuropsychological abnormalities of the asymptomatic twin may be signs of early DAT, they were not accompanied by any changes in regional cerebral metabolism or brain structure.

Dementia of the Alzheimer type (DAT) is a progressive dementing illness that often has a heritable component, particularly in cases with onset at a relatively young age. ${ }^{1}$ Studies of twins can be useful in exploring the aetiology of complex disorders such as DAT. ${ }^{2}$ Evaluation of discordant monozygotic twins can help to identify precipitating factors using the unaffected twins as controls.

We describe a pair of twins discordant for DAT. Positron emission tomography (PET), quantitative analysis of cerebral computed tomography (CT), magnetic resonance imaging (MRI), and neuropsychological testing were used to study both twins.

Address for reprint requests: J S Luxenberg, Building 10, Room 12S235B NIH, Bethesda, MD 20892, USA.

Received 3 January 1986 and in revised form 16 June 1986. Accepted 23 June 1986

\section{Methods}

Two 59 year old identical twins, one of whom was diagnosed as having DAT, were identified from the National Academy of Sciences National Research Council Twin Registry. ${ }^{3}$ Control subjects were selected from our laboratory's longitudinal study of brain function in healthy aging. ${ }^{4}$ Informed consent was obtained from the twins and from the spouse of the demented twin, as well as from control subjects. Both twins received physical examinations, routine laboratory evaluation and neuropsychological testing. Zygosity was assessed by examining peripheral blood karyotypes, HLA and erythrocyte surface antigens and ridge counts and pattern analysis of dermatoglyphics. Peripheral blood karyotypes were performed and 50 Giemsa-trypsin banded metaphases were analysed from each twin. ${ }^{5}$

\section{CT scanning}

Noncontrast CT imaging was performed ${ }^{6}$ using a General Electric 8800 CT/T scanner (General Electric Corp., Milwaukee, WI), for which full width at half max (FWHM) equaled $1 \mathrm{~mm}$. Images were obtained parallel to the externally defined inferior orbito-meatal (IOM) line. Each slice 
was $10 \mathrm{~mm}$ thick, and the interslice spacing was $7 \mathrm{~mm}$. The semi-automated method used in the analysis is described in detail elsewhere. ${ }^{67}$ A CATSEG program ${ }^{7}$ was used to quantify the total number of pixels of CSF, white matter and gray matter in each CT slice from the ranges of CT densities. To avoid apical artifacts due to beam hardening, ${ }^{8}$ this analysis was confined to a $49 \mathrm{~mm}$ horizontal segment of brain, beginning at the lowest slice containing the third ventricle. In addition, the lateral and third ventricles were outlined using a light pen, on each slice in which the structures were seen. Volumes of intracranial structures were derived by summing the number of pixels of a measure of interest across slices, and multiplying by the pixel surface area $\left(0.0064 \mathrm{~cm}^{2}\right)$ and the interslice distance $(0.7 \mathrm{~cm})$.

\section{PET scanning}

PET scans were performed ${ }^{49}$ on an ECAT II positron tomograph (ORTEC, Inc, Life Sciences Division, Oak Ridge, TN), which has a within-plane resolution of $1.7 \mathrm{~cm}$ (FWHM) and an axial resolution of $1.7 \mathrm{~cm}$. Thirty minutes prior to positron imaging, the subject's eyes were covered by patches, and ears plugged with cotton, as previously described. ${ }^{4}$ He then received an intravenous injection of 5 milliCuries of FDG ${ }^{10}$ Forty-five minutes after the injection of radionuclide, the subject was positioned in the tomograph in a plane parallel to the IOM line. Seven serial scans were taken with $14 \mathrm{~mm}$ between each slice (centre to centre). Images were corrected for attenuation with the standard ellipse. Analysis of the images was performed with a region of interest technique described previously. ${ }^{4}$

\section{MRI scanning}

Magnetic resonance imaging was performed using a Picker 0.5 Tesla cryogenic MR scanner (Picker International, Cleveland, Ohio). In the transverse plane, parallel to the IOM, 16 contiguous slices were imaged using the inversion recovery technique, with a repetition time of $4067 \mathrm{~ms}$, an inversion time of $600 \mathrm{~ms}$, and a slice thickness of $10 \mathrm{~mm}$.

\section{Neuropsychological testing}

Two brief mental status tests were performed, the MiniMental State ${ }^{11}$ and the Blessed Memory, Information and concentration Test. ${ }^{12}$ Other tests administered were the Mattis Dementia Scale; ${ }^{13}$ Wechsler Adult Intelligence Scale (WAIS); ${ }^{14}$ two tests of delayed memory from the Wechsler Memory Scale; ${ }^{1516}$ a test of comprehension of syntactic relations in single, aurally presented sentences (Syntax Comprehension Test ${ }^{17}$ ); and a test of ability to copy geometric figures of varying complexity (Extended Range Drawing Test ${ }^{17}$ ). Additional tests included the Buschke selective reminding test, ${ }^{18}$ the Boston Naming Test, ${ }^{19}$ the Block Patterns subtest of the Hiskey-Nebraska Test of Learning Aptitude, ${ }^{20}$ a test of facial recognition, ${ }^{21}$ the Controlled Word Association test, ${ }^{22}$ the Trail Making Test, ${ }^{23}$ Raven's Progressive Matrices, ${ }^{24}$ the Stroop Color WordInterference Task, ${ }^{25}$ and the Porteus Maze Test. ${ }^{26}$

\section{Case histories}

HH, the DAT patient, is a 59 year old carpenter and mason, with a 7 year history of progressive cognitive decline. His family first noted personality changes, with jealousy and paranoid ideation. He lost appropriate concern for safety while working high in buildings under construction. Memory impairment became obvious in 1980. Electroencephalography (EEG), physical and laboratory evaluations failed to reveal causes of cognitive impairment other than DAT. Subsequently, he developed word finding difficulty and has been unable to work since. He had had periodic bouts of depression, unresponsive to antidepressant therapy. There is no history of depression prior to onset of his dementing illness.

The patient is a first born twin, product of an uncomplicated pregnancy. He has a past history of peptic ulcer disease and duodenitis, treated at one time with cimetidine. Past medical history was otherwise unremarkable. There is no history of hypertension, head trauma, boxing, or drug abuse. He smokes one to two packs of cigarettes daily, and abstains from alcohol. Physical examination in 1985 revealed blood pressure of $178 / 90 \mathrm{~mm} \mathrm{Hg}$. No abnormalities were noted on general physical examination except a right femoral bruit. On neurological examination the patient was alert, cooperative, and cheerful. Recent and remote memory were impaired. He was disoriented to date, time of day, and place. Speech was fluent and without paraphasias. Marked word-finding difficulty was noted in free speech as well as upon confrontation naming. He had difficulty repeating sentences longer than three words, and was able to follow two step but not three step commands. He was acalculic and agraphic with ideomotor and marked ideational apraxia. Cranial nerves were intact. Sensation was normal for pin, light touch, vibration and position. Strength and muscle bulk were normal; mild cogwheel rigidity was present in both arms. A 2-6 Hz tremor was present when arms were extended. Deep tendon reflexes were normal, with equivocal plantar reflexes bilaterally. Glabellar and snout reflexes were present, palmomental and grasp reflexes were absent. Gait was normal. Blessed Memory, Information, and Concentration Test (BMICT) ${ }^{12}$ score was 9/37; Mini-Mental State (MMS) ${ }^{11}$ score was $3 / 30$. Chest radiograph showed evidence of old granulomatous disease. Brain CT showed diffuse atrophy. EEG was normal. The electrocardiogram (ECG) showed left atrial enlargement and a left anterior fascicular block.

WH, the unaffected identical twin of $\mathrm{HH}$, is a carpenter and mason who manages his own construction business. He has been in excellent health except for peptic ulcer disease treated in 1960 with a vagotomy. He has no complaint of memory impairment, and the family has not noted any cognitive problems. He smokes two packs daily, and does not drink alcohol. Physical examination in 1985 was unremarkable except for a contact dermatitis of both hands, a grade III/VI holosystolic murmur at the cardiac apex, and frequent ectopy. Neurological examination was normal; the patient demonstrated excellent memory for recent and distant events. His BMICT score was $34 / 37$, and MMS score was $26 / 30$. Chest radiograph showed old granulomatous disease. Brain CT and EEG were normal. ECG showed left atrial enlargement and frequent premature ventricular complexes.

Both twins were born and raised in rural Arkansas, and graduated from high school. They served in the Army together, were partners in the construction business, and have lived within miles of each other throughout their lives. 
Table 1 Red blood cell and HLA phenotypes

Red cell antigens

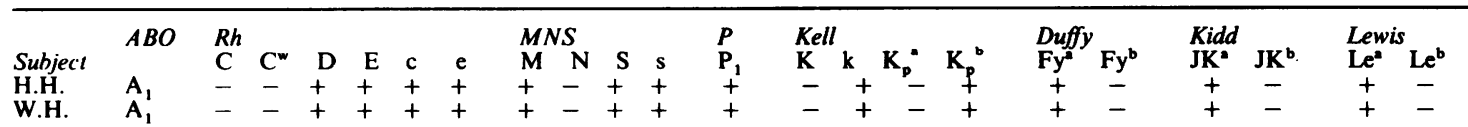

$H L A$ antigen

\begin{tabular}{lllll}
\hline Subject & $A$ & $B$ & $C$ & $D R$ \\
H.H & 1,3 & 8,61 & W2 & 2,3 \\
W.H. & 1,3 & $\mathbf{8 , 6 1}$ & W2 & $\mathbf{2 , 3}$
\end{tabular}

There is no family history of dementing illnesses, Down syndrome, haematopoetic malignancy, or psychiatric disorders.

\section{Results}

Red blood cell and HLA phenotypes were compatible with the twins' monozygotic status (table 1). Hypodiploidy was not detected, and no detectable differences in chromosomal polymorphisms were found.

Digital patterns of both twins were predominantly loops ulnar and were the same on all except the index fingers. A total finger ridge count could not be done accurately due to areas of ridge atrophy in both sub- jects. Their palms were very similar, with few patterns and bilateral bridging of the proximal and distal transverse palmar creases. All axial triradii were proximally placed, and summed atd angles were similar $\left(80.5^{\circ}\right.$ unaffected, $80.0^{\circ}$ affected). Summed a-b ridge counts also were similar (72 and 75). The most highly correlated measurement in like-sexed monozygotic twins is the total finger ridge count $(0.95 \pm 0.01)$, although the summed a-b and atd measurements also demonstrate a major genetic influence (correlations of $0.82 \pm 0.04$ and $0.63 \pm 0.09$, respectively). ${ }^{27}$

The neuropsychological data (table 2) confirm the presence of cognitive deficiency in the affected twin (HH). He had profound impairment of recent and

Table 2 Neuropsychological test scores

\begin{tabular}{|c|c|c|c|c|}
\hline Test & Maximum score & $\begin{array}{l}\text { Control }(n=8) \\
(\text { mean } \pm S D)\end{array}$ & $\boldsymbol{W H}$ & $\boldsymbol{H} H$ \\
\hline $\begin{array}{l}\text { Mattis dementia scale } \\
\text { Wechsler adult intelligence scale (WAIS) }\end{array}$ & 144 & $142 \pm 2$ & $136^{*}$ & $47^{*}$ \\
\hline $\begin{array}{l}\text { Wechsler adult intelligence scale (WAIS) } \\
\text { Full scale IQ } \\
\text { Verbal comprehension deviation quotient } \\
\text { Memory/distractibility DQ } \\
\text { Perceptual organization DQ }\end{array}$ & & $\begin{array}{l}122 \pm 12 \\
123 \pm 13 \\
113 \pm 16 \\
118 \pm 12\end{array}$ & $\begin{array}{c}100 \\
113 \\
91 \\
89^{*}\end{array}$ & $\begin{array}{l}52^{*} \\
57^{*} \\
48^{*} \\
46^{*}\end{array}$ \\
\hline $\begin{array}{l}\text { Wechsler memory scale } \\
\text { Immediate story recall } \\
\text { Immediate visual reproduction } \\
\text { Delayed story recall } \\
\text { Delayed visual reproduction }\end{array}$ & $\begin{array}{l}45 \\
14 \\
45 \\
14\end{array}$ & $\begin{array}{l}21 \pm 5 \\
10 \pm 3 \\
17 \pm 6 \\
7 \pm 3\end{array}$ & $\begin{array}{l}12 \\
5 \\
5^{*} \\
1\end{array}$ & $\begin{array}{l}0^{*} \\
0^{*} \\
0^{*} \\
0^{*}\end{array}$ \\
\hline $\begin{array}{l}\text { Buschke selective reminding } \\
\text { Total recall over } 8 \text { trials }(\max =72 \text { ) } \\
\text { Total long-term memory recall } \\
30 \text { minute delayed recall }\end{array}$ & $\begin{array}{r}72 \\
63 \\
9\end{array}$ & $\begin{array}{l}65 \pm 7 \\
50 \pm 13 \\
8 \pm 1 \cdot 3\end{array}$ & $\begin{array}{l}51 * \\
28 \\
5 *\end{array}$ & $\begin{array}{r}10^{*} \\
2^{*} \\
0^{*}\end{array}$ \\
\hline $\begin{array}{l}\text { Language } \\
\text { Boston naming (odd items only) } \\
\text { Syntax comprehension test } \\
\text { Controlled word association (FAS) }\end{array}$ & $\begin{array}{l}43 \\
26\end{array}$ & $\begin{array}{l}38 \pm 6 \\
24 \pm 2 \\
40 \pm 17\end{array}$ & $\begin{array}{l}32 \\
21 \\
28\end{array}$ & $\begin{array}{r}11^{*} \\
0^{*} \\
0^{*}\end{array}$ \\
\hline $\begin{array}{l}\text { Visuospatial function } \\
\text { Extended range drawing } \\
\text { Hiskey-Nebraska block patterns } \\
\text { Benton facial recognition } \\
\text { Porteus mazes (test age) }\end{array}$ & $\begin{array}{l}24 \\
32 \\
54 \\
17\end{array}$ & $\begin{array}{l}20 \pm 4 \\
14 \pm 5 \\
46 \pm 4 \\
15 \pm 1 \cdot 5\end{array}$ & $\begin{array}{l}15 \\
10 \\
44 \\
12^{*}\end{array}$ & $\begin{array}{c}1^{*} \\
1^{*} / c^{*} \\
4^{*}\end{array}$ \\
\hline $\begin{array}{l}\text { Trailmaking } \\
\text { Trail A (time-sec) } \\
\text { Trail A (time-sec) } \\
\text { Raven's coloured matrices } \\
\text { Stroop color word-interference task }\end{array}$ & 36 & $\begin{array}{l}42 \pm 20 \\
74 \pm 20 \\
33 \pm 2 \\
37 \pm 6\end{array}$ & $\begin{array}{c}44 \\
110 \\
24^{*} \\
16^{*}\end{array}$ & $\begin{array}{c}d / c \dagger \\
d / c \dagger \\
d / c \dagger \\
1^{*}\end{array}$ \\
\hline
\end{tabular}

* Differs from control mean by more than 2 SD.

+Test attempted but discontinued due to patient's inability to follow instructions. 

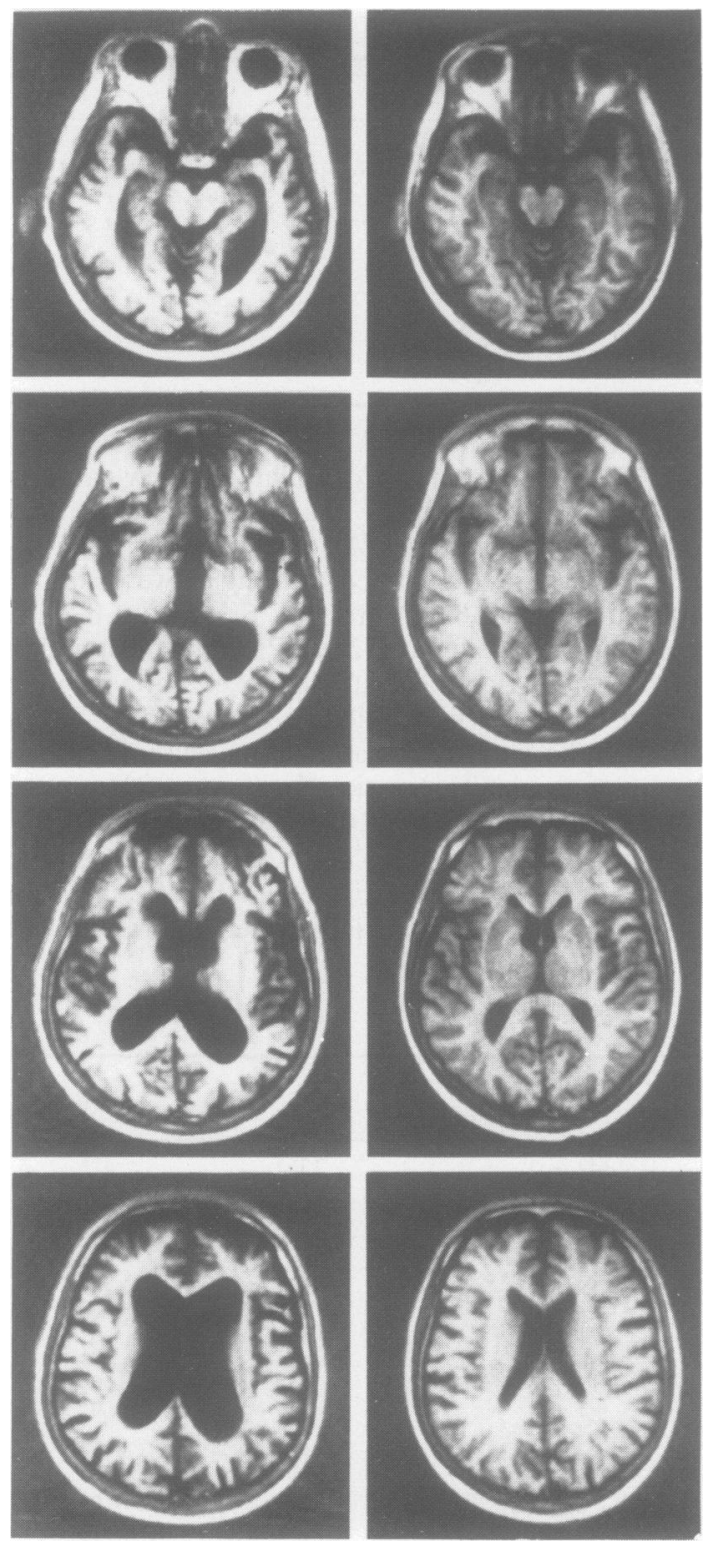

Fig 1 Transverse MRI scans of affected twin (left) and asymptomatic twin (right) taken at comparable levels.

Table 3 CT volumes-first scan remote memory, of visuospatial function, language, and of other higher cognitive functions. Although his asymptomatic brother (WH) had normal overall intelligence as measured by the WAIS Full Scale IQ, several neuropsychological test scores suggested some minimal brain dysfunction. The 24 point difference between the WAIS Verbal Comprehension Deviation Quotient (which summarises tests of verbal fund of knowledge) and the WAIS Perception Organization Deviation Quotient (which summarises tests of visuospatial construction) is greater than that found in the controls ( $p<0.05$, by $Z$ scores). Furthermore, his scores on tests of memory, planning and foresight, abstract visual reasoning, and susceptibility to perceptual interference fell below normal limits. Rather than reflecting brain dysfunction, these low scores may be due to his emotional turmoil when tested; his twin brother's deterioration was dramatically illustrated for him during their concurrent hospital stay, and his brother-in-law had died of cancer immediately prior to this study. Moreover, the control subjects with which he was compared had a somewhat higher level of education (mean $=14 \pm 1.6$ (SD) years). Nonetheless, his disproportionate difficulty in tests of visuospatial construction, visual reasoning, and visual mazes is not easy to reconcile with his successful career in construction.

MRI of the brain of the asymptomatic twin revealed no abnormality, whereas MRI of the brain of the demented twin showed marked loss of cortical gray matter, enlargement of sulcal spaces and ventricular dilatation (fig 1). Quantitative analysis of the CT data revealed significant differences from age matched controls for the affected twin only (table 3 ).

PET scanning (table 4, fig 2) showed a normal pattern of cerebral glucose metabolism in the asymptomatic twin. Scans of the affected twin showed frontal and parietal lobe hypometabolism and pronounced left-right asymmetry of metabolism in the association cortices of the frontal and parietal lobes, with regional cerebral metabolic rate for glucose $\left(\mathrm{rCMR}_{\mathrm{glc}}\right)$ lower on the left than on the right (table 5).

\section{Discussion}

This study shows that PET, quantitative CT, MRI, and neuropsychological tests distinguish the changes

\begin{tabular}{lccc}
\hline & Demented $t$ win & Unaffected twin & Healthy controls \\
\hline Volumes $(\mathrm{ml})$ & & & $410 \pm 20 \dagger$ \\
Grey matter & $277^{*}$ & 392 & $350 \pm 35$ \\
White matter & 407 & 357 & $41 \pm 20$ \\
Cerebrospinal fluid & $143^{*}$ & 17 & $1 \cdot 6 \pm 0 \cdot 8$ \\
Volumes (ml) & $3 \cdot 9^{*}$ & $1 \cdot 6$ & $16 \cdot 6 \pm 8 \cdot 6$ \\
Third ventricle & $69^{*}$ & $10 \cdot 7$ & $18 \cdot 8 \pm 8 \cdot 4$ \\
Right lateral ventricle & $77 \cdot 5^{*}$ & $9 \cdot 8$ & 8 \\
Left lateral ventricle & &
\end{tabular}

$*=$ Differs from values of 11 age and sex matched healthy control subjects by more than $2 \mathrm{SD}$.

$\dagger=$ Mean \pm SD. 
Table 4 Cerebral metabolic rate for glucose

\begin{tabular}{|c|c|c|c|}
\hline Region & Healthy controls $N=17$ & Affected twin & Unaffected twin \\
\hline $\begin{array}{l}\text { Right frontal lobe } \\
\text { Left frontal lobe } \\
\text { Right parietal lobe } \\
\text { Left parietal lobe } \\
\text { Right temporal lobe } \\
\text { Left temporal lobe } \\
\text { Right occipital lobe } \\
\text { Left occipital lobe } \\
\text { Right sensory-motor cortex } \\
\text { Left sensory-motor cortex }\end{array}$ & $\begin{array}{l}5.60 \pm 1.27 *(96.1 \pm 8.3) \dagger \\
5.61 \pm 1.29(96.7 \pm 7.3) \\
5.49 \pm 1.19(94.3 \pm 6.3) \\
5.55 \pm 1.32(94.8 \pm 6.6) \\
4.65 \pm 0.96(80.0 \pm 7.4) \\
4.62 \pm 0.92(79.8 \pm 8.8) \\
5.54 \pm 1.16(95.8 \pm 10.0) \\
5.57 \pm 1.15(96.1 \pm 8.3) \\
5.74 \pm 1.30 \\
5.95 \pm 1.40\end{array}$ & $\begin{array}{l}3.28(91.9) \\
2.96 \ddagger(83.0) \\
3.33(93.2) \\
2.74 \ddagger(76 \cdot 7) \ddagger \\
3.30(92.4) \\
3.19(89.4) \\
4.76(133.4) \ddagger \\
4.66(130.6)_{\ddagger}^{\ddagger} \\
3.58 \\
3.57\end{array}$ & $\begin{array}{l}4 \cdot 41(91 \cdot 2) \\
4 \cdot 64(96 \cdot 0) \\
4 \cdot 64(96 \cdot 0) \\
4 \cdot 79(99 \cdot 1) \\
4 \cdot 20(87 \cdot 0) \\
4 \cdot 29(88 \cdot 9) \\
4 \cdot 58(94 \cdot 8) \\
4 \cdot 75(98 \cdot 3) \\
4 \cdot 73 \\
4 \cdot 90\end{array}$ \\
\hline
\end{tabular}

* $=$ Mean \pm SD Mg glucose $/ 100 \mathrm{~g}$ Brain tissue $/$ minute.

$\dagger=$ Mean \pm SD, \% mean sensory-motor cortex value calculated as the lobar metabolic rate divided by the metabolic rate of the sensory motor cortex, an area relatively preserved in DAT.

$+=$ Differs from control mean $(p<0.05)$.

of DAT in a pair of identical twins apparently discordant for this malady. Unlike many past studies, the cerebral anatomical and metabolic normality of the asymptomatic twin was documented. ${ }^{28} 29$ Twins have been shown to have similar abilities on neuropsychological testing, ${ }^{30}$ and monozygotic twins are more similar than dizygotic twins. ${ }^{31}$ The marked discordance in neuropsychological functioning in these twins can best be attributed to the pathological process of DAT.

Monozygosity has rarely been confirmed in prior reports of twins discordant for DAT. The twins described by Davidson and Robertson ${ }^{29}$ were considered monozygotic on the basis of similarity of appearance and personality. Hunter et al' $\mathrm{s}^{28}$ pair of twins were dermatoglyphically similar, and shared

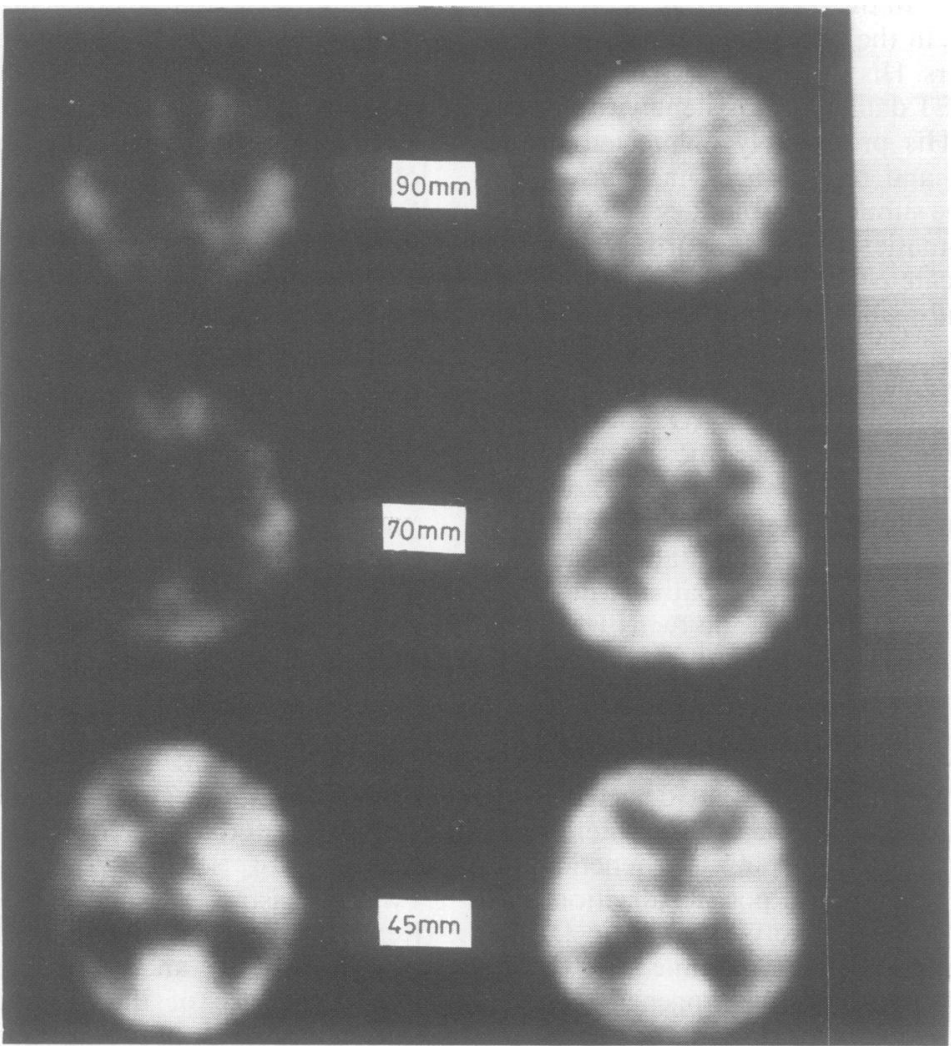

Fig 2 Images of regional cerebral metabolic rate for glucose $\left(\boldsymbol{r} C M \boldsymbol{R}_{\mathrm{glc}}\right)$. Scale refers to $\mathrm{mg}$ glucose $/ 100 \mathrm{~g}$ brain tissue/minute. The affected twin is on the left, the asymptomatic twin is on the right. The slice levels refer to distance in $\mathrm{mm}$ above the IOM line. 
Table 5 Asymmetry of cerebral metabolic rate for glucose

\begin{tabular}{|c|c|c|c|}
\hline Region & Healthy controls $N=17$ & Affected twin & Unaffected twin \\
\hline $\begin{array}{l}\text { Frontal } \\
\text { Parietal } \\
\text { Temporal } \\
\text { Occipital } \\
\text { Sensorimotor }\end{array}$ & $\begin{array}{r}-0.3 \% \pm 3.9 \% \\
-0.6 \% \pm 8.7 \% \\
0.5 \% \pm 9.2 \% \\
-0.7 \% \pm 4.8 \% \\
-3.3 \% \pm 6.4 \%\end{array}$ & $\begin{array}{c}10 \cdot 2 \%{ }^{*} \\
19 \cdot 4 \% * \\
3 \cdot 3 \% \\
2 \cdot 1 \% \\
0 \cdot 3 \%\end{array}$ & $\begin{array}{l}-5 \cdot 1 \% \\
-3 \cdot 1 \% \\
-2 \cdot 2 \% \\
-3 \cdot 6 \% \\
-3 \cdot 5 \%\end{array}$ \\
\hline
\end{tabular}

* Differs from control $(\mathrm{p}<0.05)$.

blood group phenotypes and biochemical markers. Reports of twins concordant for DAT lacked laboratory evidence of monozygosity. ${ }^{32-34}$ The twins in this report have identical HLA analysis, and share 22 red blood cell antigens. Dermatoglyphic analysis also showed remarkable similarity.

Conclusive determination of discordance for DAT in life is difficult, because of possible differences in age of onset of DAT. In one set of identical twins who were both affected, age of onset differed by 14 years. ${ }^{32}$ Doubts as to the true discordant status of three pairs of twins previously reported in the literature have been raised. ${ }^{282932}$ In the present study, a progressive dementing illness in the affected twin has been documented for 5 years. His clinical picture, as well as his CT, MRI, and PET data, are consistent with the diagnosis of DAT. His presumably unaffected brother remains healthy, and reports no symptoms of cognitive decline. The subtle abnormalities demonstrated by the asymptomatic twin on neuropsychological testing may indicate early signs of disease, but only further serial study will demonstrate if these abnormalities progress.

Previous studies of twins have not produced clear evidence of a genetic aetiology in AD. In one report of DAT, equivalent concordance rates were found in monozygotic $(73 \%)$ and dizygotic $(75 \%)$ twins. ${ }^{35}$ However, the small numbers of twins with DAT reported in the world literature limit adequate evaluation. In a case-control study of patients in mental hospitals, risk of DAT to dizygotic twins was $8.0 \%$, but $42 \cdot 8 \%$ to monozygotic twins. ${ }^{36}$

Hypodiploidy has been reported in DAT, ${ }^{37}$ but Jarvik $^{37}$ reported similar prevalence of hypodiploidy in elderly male twins with and without clinically diagnosed DAT. Hypodiploidy was not detected in our twins, and banding studies revealed no differences in their chromosomal polymorphisms. Genetic alterations occurring after several post-fertilization mitoses have been hypothesised to play a role in DAT ${ }^{38}$ Monozygotic twins separate some time after the first mitosis, and chromosomal heterogeneity can be sought in monozygotic twins discordant for DAT.

Studies of rCMR $_{\text {glc }}$ with PET have shown that patients with DAT have lower metabolic rates than do controls, ${ }^{39} 40$ particularly in parietal and temporal regions. ${ }^{173941-43}$ Furthermore, right-left asymmetries in the $\mathrm{rCMR}_{\mathrm{glc}}$ of these regions correlate with specific "asymmetry" patterns of neuropsychological deficits. ${ }^{1744}$ Our patient with DAT showed marked asymmetry of $\mathrm{rCMR}_{\text {glc }}$ in the frontal and parietal regions similar to that reported $173941-43$ and his clinically normal twin showed no such asymmetries. The normal metabolic pattern in the asymptomatic twin may imply absence of DAT, but not enough is known of the ability of PET to detect metabolic abnormalities very early in the disease process.

Quantitative analysis of ventricular volumes using CT has been shown to be more sensitive than standard planar analysis in detecting differences between DAT patients and healthy subjects. ${ }^{45}$ The CT and MRI scans of the twin with DAT showed significant loss of gray matter, and enlargement of the third and lateral ventricles, consistent with changes seen in DAT. ${ }^{45} 46$

This is the first report of twins discordant for DAT studied with metabolic and quantitative neuroanatomic imaging techniques. PET scanning, quantitative CT, and MRI scans all showed abnormalities in the affected twin compared to both healthy control subjects and his asymptomatic twin brother. The asymptomatic twin showed abnormalities on several neuropsychological tests compared to healthy controls. No abnormalities of PET, quantitative CT or MRI scans were seen in the asymptomatic twin. If he develops DAT, his PET, quantitative CT, and MRI studies will be among the earliest in the course of DAT yet reported.

The authors thank the twins and their families for their cooperation. This work is one of a series of collaborative studies which make use of the National Academy of Sciences-National Research Council Twins Registry. The use of records provided by the Registry, the Department of Defense, the Veterans Administration, and the National Archives and Record Service of the General Services Administration in the preparation of this material is acknowledged, but it is not to be construed as implying official approval by them of the conclusions presented. 
For future identification, NIH patient numbers are 1800498 for H.H. and 1800814 for W.H.

\section{References}

1 Heston LL. Dementia of the Alzheimer type: a perspective from family studies. In: Katzman R, ed. Biologic Aspects of Alzheimers Disease. 15th ed, Cold Spring Harbor, NY, Banbury Report, Cold Spring Harbor Laboratory, 1983.

2 Eldridge R. Twin studies and the etiology of complex neurological disorders, In: Ludlow CL, Cooper JA, eds. Genetic Aspects of Speech and Language Disorders. New York: Academic Press, 1983:109-20.

3 Jablon S, Neel JV, Gershowitz H, Atkinson GF. The NAS-NRC twin panel: methods of construction of the panel, zygosity diagnosis, and proposed use. Am J Hum Genet 1967;19:133-61.

4 Duara R, Grady C, Haxby J, et al. Human brain glucose utilization and cognitive function in relation to age. Ann Neurol 1984;16:702-13.

5 White BJ, Crandall C, Goudsmit J, et al. Cytogenetic studies of familial and sporadic Alzheimer disease. Am J Med Genet 1981;10:77-89.

6 Schwartz M, Creasey H, Grady CL, et al. Computed tomographic analysis of brain morphometrics in 30 healthy men, aged 21 to 81 years. Ann Neurol 1985; 17:146-57.

7 DeLeo JM, Schwartz M, Creasey H, et al. Computerassisted categorization of brain computerized tomography pixels into cerebrospinal fluid, white matter, and gray matter. Comp Biomed Res 1985;18:79-88.

8 Gado $\mathbf{M}$, Phelps $\mathbf{M}$. The peripheral zone of increased density in cranial computed tomography. Radiology 1975;117:71-4.

9 Duara R, Horwitz B, Grady CL, et al. A matrix method to quantitate functional interactions among brain regions: application to state of reduced sensory input. Soc Neurosci Abstr 1983;9:1171.

10 Shiue CY, Salvadori PA, Wolf AP, et al. A new improved synthesis of 2-deoxy-2-[18-F]fluoro-Dglucose from 18-F-labeled acetyl hypofluorite. $J$ Nucl Med 1982;23:899-903.

11 Folstein MF, Folstein SE, McHugh PR. "Mini-mental state"-a practical method for grading the cognitive state of patients for the clinician. J Psychiatr Res 1975;12:189-98

12 Blessed G, Tomlinson BE, Roth $\mathrm{M}$. The association between quantitative measures of dementia and of senile change in the cerebral grey matter of elderly subjects. Br J Psychiatry 1968;114:797-811.

13 Mattis S. Mental status examination for organic mental syndrome in the elderly patient, In: Bellack L, Karasu TB, eds. Geriatric Psychiatry. New York: Grune and Stratton, 1976.

14 Wechsler DA. Wechsler Adult Intelligence Scale. New York: Psychological Corporation, 1955:1-300.

15 Wechsler DA. A standardized memory scale for clinical use. J Psychol 1945;19:87-95.

16 Russell EW. A multiple scoring method for the assessment of complex memory functions. $J$ Consult Clin Psichol 1975;43:800-9.
17 Haxby JV, Duara R, Grady CL, et al. Relations between neuropsychological and cerebral metabolic asymmetries in early Alzheimer's disease. J Cereb Blood Flow Metabol 1985;5:193-200.

18 Buschke $\mathrm{H}$. Selective reminding for analysis of memory and learning. J Verbal Learn Verbal Behav 1973;12: 543-50.

19 Kaplan E, Goodglass H, Weintraub S. Boston Naming Test (Experimental Version). Boston: Boston Veterans Administration Medical Center, 1976.

20 Hiskey MS. Manual: Hiskey-Nebraska Test of Learning Aptitude. Lincoln, Nebraska: College View Printers, 1965.

21 Benton AL, Van Allen MW. Test of Facial Recognition Manual. Ames, Iowa: Neurosensory Center Publication No. 287, University of Iowa, 1973.

22 Benton AL. The measurement of aphasic disorders, In: Velasquez AC, ed. Aspectos Patologicos Del Langage. Lima: Centro neuropsicologico, 1973.

23 Reitan RM. Validity of the trail making test as an indicator of organic brain damage. Percept Mot Skills 1958;8:271-6.

24 Raven JC, Court JH, Raven J. Manual for Raven's Progressive Matrices and Vocabulary Scales. London: HK Lewis, 1976.

25 Golden CJ. The Stroop Color and Word Test: A Manual for Clinical and Experimental Uses. Chicago: Stoelting, 1978.

26 Porteus SD. Porteus Maze Test: Fifty Years Application. Palo Alto: Ca, Pacific Books, 1965

27 Holt SB. The Genetics of Dermal Ridges. Springfield: Chas. C. Thomas, 1968.

28 Hunter R, Dayan AD, Wilson J. Alzheimer's disease in one monozygotic twin. J Neurol Neurosurg Psychiatry 1972;35:707-10.

29 Davidson EA, Robertson EE. Alzheimer's disease with acne rosacea in one of identical twins. J Neurol Neurosurg Psychiatry 1955;18:72-7.

30 Jarvik LF, Kallmann FJ, Falek A. Intellectual changes in aged twins. $J$ Gerontol 1962;17:289-94.

31 Jarvik LF, Blum JE, Varma AO. Genetic components and intellectual functioning during senescence: a 20-year study of aging twins. Behav Genet 1972; 2:159-71

32 Cook RH, Schneck SA, Clark DB. Twins with Alzheimer's disease. Arch Neurol 1981;38:300-1.

33 Sharman MG, Watt DC, Janota I, Carrasco LH. Case report-Alzheimer's disease in a mother and identical twin sons. Psychol Med 1979;9:771-4.

34 Embry C, Lippmann S. Presumed Alzheimer's disease beginning at different ages in two twins. $J$ Am Geriatr Soc 1985;33:61-2.

35 Jarvik LF. Genetic factors and chromosomal aberrations in Alzheimer's disease, senile dementia, and related disorders, In: Katzman R, Terry RD, Bick KL, eds. Alzheimer's Disease: Senile Dementia and Related Disorders (Ageing, Vol. 7). New York: Raven Press, 1978.

36 Kallmann FJ, Sander G. Twin studies on senescence. Am J Psychiatry 1949;106:29-36.

37 Jarvik LF, Altshuler KZ, Kato T, Blumner B. Organic brain syndrome and chromosome loss in aged twins. Dis Nerv Syst 1971;32:159-70. 
38 Crapper-McLachlan DR, Lewis PN. Alzheimer's disease: errors in gene expression. Can J Neurol Sci 1985;12:1-5.

39 Frackowiak RSJ, Pozzilli C, Legg NJ, et al. Regional cerebral oxygen supply and utilization in dementia: a clinical and physiological study with oxygen-15 and positron tomography. Brain 1981;104:753-78.

40 de Leon MJ, Ferris SH, George AE, et al. Computed tomography and positron emission transaxial tomography evaluations of normal aging and Alzheimer's disease. J Cereb Blood Flow Metabol 1983;3:391-4.

41 Friedland RP, Budinger TF, Ganz E, et al. Regional cerebral metabolic alterations in dementia of the Alzheimer type: positron emission tomography with [18-F]fluorodeoxyglucose. J Comp Assist Tomogr 1983;7:590-8.

42 Chase TN, Foster NL, Fedio P, et al. Regional cortical dysfunction in Alzheimer's disease as determined by positron emission tomography. Ann Neurol 1984; 15S:S170-S174.

43 Duara R, Grady CL, Haxby JV, et al. Positron emission tomography in Alzheimer's disease. Neurology 1986;36:879-87.

44 Foster NL, Chase TN, Fedio P, et al. Alzheimer's disease: focal cortical changes shown by positron emission tomography. Neurology 1983;33:961-5.

45 Gado M, Hughes CP, Danziger W, et al. Volumetric measurements of the cerebrospinal fluid spaces in demented subjects and controls. Radiology 1982; 144:535-8.

46 Creasey H, Schwartz M, Frederickson H, et al. Quantitative computed tomographic analysis in Alzheimer's disease. Neurology (in press.) 